\title{
Epstein Barr virus (EBV) encoded small RNAs: Targets for detection by in situ hybridisation with oligonucleotide probes
}

\author{
G Khan, P J Coates, H O Kangro, G Slavin
}

\begin{abstract}
Aims: To develop a rapid, sensitive, and specific non-isotopic in situ hybridisation (NISH) procedure for the detection of Epstein-Barr virus in formalin fixed, parafin wax embedded tissues.

Methods: Two low molecular weight RNAs, designated EBER-1 and EBER-2 (Epstein-Barr encoded RNA), were used: cells latently infected with EBV secrete large amounts of EBERs. The method uses digoxigenin labelled anti-sense oligonucleotides, corresponding

sequences in EBER-1 and EBER-2.

Results: The use of these probes, in conjunction with high temperature microwave denaturation, ensured that the technique was considerably more sensitive than other in situ hybridisation techniques for detecting EBV. Furthermore, the hybridisation signal was morphologically distinct in that only the nucleus and not the nucleolus give a positive signal. No cross-hybridisation was observed with cells infected with other lymphotropic herpes viruses.

Conclusion: The sensitivity, simplicity, and rapidity of this technique make it ideal for diagnostic use, and for studies investigating the role of this virus in neoplastic disease.
\end{abstract}

Epstein-Barr virus (EBV) is a large (172 kilobase), double stranded DNA virus, designated the $\gamma$ herpes virus. This ubiquitous transforming virus ${ }^{12}$ is known to infect both epithelial $^{3}$ and lymphoid cells. ${ }^{12}$ More than $90 \%$ of the world population is seropositive for $\mathrm{EBV}^{4}$

In less than three decades since the discovery of EBV in a Burkitt's lymphoma cell culture, ${ }^{5}$ this virus has been shown to be associated with a whole range of benign and malignant human diseases. Typically, EBV has been associated with two geographically restricted malignancies, Burkitt's lymphoma and nasopharyngeal carcinoma, ${ }^{67}$ and it is known to be an aetiological agent of infectious mononucleosis. ${ }^{8}$ More recently, EBV has been implicated in the aetiology of post-transplantation lymphoproliferative disorders, ${ }^{9}$ Hodgkin's disease, ${ }^{10}$ brain lymphomas, ${ }^{11}$ oral hairy leucoplakia, ${ }^{12}$ and $T$ cell lymphomas. ${ }^{13}$ The ubiquitous nature of EBV and its diverse association with human diseases emphasises the need for sensitive, specific, and rapid techniques which can detect the presence of the virus at the cellular level. Several techniques have been used for showing the presence of EBV, including serology, ${ }^{14}$ Southern blotting, ${ }^{15}$ polymerase chain reaction ${ }^{116}$ and in situ hybridisation. ${ }^{10-12}$ However, of these only in situ hybridisation allows the virus to be localised at the cellular level. In recent years it has been modified to give very sensitive results, even with non-isotopically labelled probes. Using digoxigenin labelled $B a m H 1 W$ fragment probe, the internal repeat sequence of $\mathrm{EBV}$, single copies of EBV can be detected in infected cells. ${ }^{1718}$ The interpretation of the results, however, can be very difficult if only a few copies of EBV are present, because of the dot pattern of the hybridisation signal.

EBV infection can follow one of two major pathways; either a latent cycle or a productive one, depending on the cell type infected. In B lymphocytes EBV generally establishes latent infection during which at least eight virally encoded proteins are expressed. ${ }^{19}$ In addition, two non-polyadenylated non-coding small RNAs, referred to as Epstein Barr encoded RNAs (EBER-1 and EBER-2), are also present. ${ }^{19}$ In latently infected cells EBERs are by far the most abundant gene transcripts $\left(10^{7}\right.$ copies per cell). ${ }^{20-22}$ These small RNAs, 166 and 172 nucleotides, respectively, are located in the nucleus ${ }^{23}$ where they are bound to cellular La (lupus antigen) protein $^{20}$ and EBER associated protein (EAP). ${ }^{24}$ Hence EBERs exist as ribonucleoproteins, complexed with at least two cellular proteins, and exhibit stable secondary structure. ${ }^{202224}$ Despite the high abundance of EBERs in infected cells, their function remains elusive. 222325

The detection of EBERs by in situ hybridisation using cloned EBER-1 riboprobe has recently been described and shown to be a promising technique for the detection of EBV. $^{2627}$

\section{Methods}

PREPARATION OF DNA PROBES

The BamH1 W fragment of EBV, which is the 3.1 kilobase internal repeat sequence, was cloned into the plasmid vector pAT153 and subsequently used without purification from the vector. For oligonucleotide EBER probes, two sequences of 30 nucleotides each, corresponding to positions $90-119$ and 82-111 of EBER-1 and EBER-2, respectively, were selected from their published sequence ${ }^{28}$ and synthesised using the 391 DNA synthesiser (Applied Biosystems). The sequences were designed to have high G-C content $(60 \%)$ to 
ensure the formation of stable hybrids with their targets. The oligonucleotide sequences were also selected to be complementary to target regions in EBER-1 and EBER-2, which are not bound to cellular proteins and do not contain significant secondary structure, thereby facilitating the efficiency of hybridisation. A 30 mer oligonucleotide, unrelated to EBER sequence, but having similar G-C content $(60 \%)$, was also synthesised and labelled as for EBER probes. This was used as a negative control.

All probes were labelled with digoxigenin11-dUTP (Boehringer Mannhein, Lewes, Sussex). The BamH1 $W$ fragment probe was labelled by nick translation using a commercially available kit (Gibco, Paisley, Scotland), following the manufacturer's protocol. The synthetic oligonucleotide probes were endlabelled by tailing with terminal transferase, as described. ${ }^{29}$ Briefly, the labelling reaction was set up by combining the following compounds on ice: $1 \mu \mathrm{l}$ oligonucleotide $(1 \mu \mathrm{g} / \mu) ; 4 \mu \mathrm{l}$ of 5 $\times$ concentrated tailing buffer (TRIS-HCl 125 $\mathrm{mmol} / \mathrm{l}, \mathrm{pH} 6 \cdot 6$, potassium cacodylate $1 \mathrm{~mol} / \mathrm{l}$, bovine serum albumin $1.25 \mathrm{mg} / \mathrm{ml}) ; 2 \mu \mathrm{l}$ $\mathrm{CoCl}_{2}$ (50 mmol/1); $1 \mu \mathrm{l} \mathrm{Dig-dUTP} \mathrm{labelling}$ mixture (Dig-dUTP $1 \mathrm{mmol} / 1$, dATP $9 \mathrm{mmol} /$ 1, TRIS- $\mathrm{HCl} 10 \mathrm{mmol} / \mathrm{l}, \mathrm{pH} \mathrm{7 \cdot 5)}$. The reaction volume was increased to $17 \mu \mathrm{l}$ with sterile distilled water and $3 \mu \mathrm{l}$ (55 Units) of terminal transferase (Stratech Scientific Ltd, Luton, UK) was added. The mixture was incubated for 30 minutes at $37^{\circ} \mathrm{C}$. The reaction was terminated by adding $1 \mu \mathrm{l}$ of $0 \cdot 2 \mathrm{M}$ EDTA and the labelled oligonucleotides were purified by repeated ethanol precipitation in the presence of $100 \mu \mathrm{g}$ salmon sperm DNA.

Before ethanol precipitation of the labelled oligonucleotide probes, $2.5 \mu \mathrm{l}(125 \mathrm{ng})$ of each probe was aliquoted out for the determination of the tail length and the labelling efficiency by electrophoresis through a $20 \%$ polyacryamide gel. Gels were stained with ethidium bromide, blotted on to a nitrocellulose membrane, and the labelled probe detected as described. ${ }^{29}$

\section{CELL CULTURE AND TISSUES}

Human cytomegalovirus and human herpes virus 6 (HHV-6) were cultured in human foreskin fibroblasts and HSB-2 cell line, respectively. B95-8 (EBV producer cell line), Namalwa (Burkitt's lymphoma cell line containing two copies of EBV), EBV transformed lymphoblastoid cell line, and Ramos (EBV negative cell line) were also grown in cell suspension culture. The cells were fixed in $10 \%$ formol-saline overnight at room temperature, pelleted by centrifugation, and embedded in $0.5 \mathrm{ml}$ of $2 \%$ agar. The agar pellets were dissected into small blocks and processed to paraffin wax on an automatic tissue processor, according to standard laboratory procedure.

Formalin fixed, paraffin wax embedded tissues were retrieved from the departmental files. These consisted of five cases of undifferentiated nasopharyngeal carcinoma, five cases of Hodgkin's disease, and one case of nonHodgkin's lymphoma. Except for two cases of Hodgkin's disease, all other cases were positive for EBV by polymerase chain reaction (PCR) or NISH or both. ${ }^{16}{ }^{17}$ Sections of normal tonsil were used as negative controls in addition to fibroblast and HSB-2 cell cultures.

HYBRIDISATION

In situ hybridisation using $\mathrm{BamH} 1 \mathrm{~W}$ fragment was carried out, as previously described. ${ }^{17} \mathrm{~A}$ similar approach was adopted for EBER hybridisation. In initial experiments a range of variables were evaluated for their effects on the detection of EBERs. These included stringency conditions for hybridisation and post-hybridisation washes, the temperature of denaturation, the degree of proteinase $\mathrm{K}$ digestion and the concentration of probes.

Briefly, $5 \mu \mathrm{m}$ sections on sialinised slides were heated for one hour at $70^{\circ} \mathrm{C}$, dewaxed in xylene, and the endogenous peroxidase activity blocked with $0.5 \%$ hydrogen peroxide in methanol. The sections were digested with proteinase $\mathrm{K}$ in TRIS-buffered saline ( $\mathrm{pH} \mathrm{7.6)}$ ) for 15 minutes at $37^{\circ} \mathrm{C}$, dehydrated, and dried. The labelled probes were diluted to a concentration of $0.1 \mu \mathrm{g} / \mathrm{ml}$ in hybridisation medium $(50 \%$ formamide, $5 \%$ dextran sulphate, $2 \times$ SSC). Depending on the size of the section, 8-15 $\mu 1$ of the diluted probe was spotted on to the tissue sections and a coverslip placed on top. Probe and target EBER RNA were simultaneously denatured at about $104^{\circ} \mathrm{C}$ in a microwave oven (Toshiba ER-665) for eight minutes (one minute at medium setting followed by seven minutes at low setting). ${ }^{18} 30$ The sections were subsequently hybridised at $42^{\circ} \mathrm{C}$ overnight in a hot air oven.

The non-specific or unbound probe was removed by post-hybridisation washes consisting of two 10 minute washes in each of the following: $2 \times$ SSC (sodium citrate, sodium chloride) at room temperature, $0.1 \times \mathrm{SSC}$ at $55^{\circ} \mathrm{C}$, and finally $2 \times$ SSC at room temperature. The hybridisation signal was detected by a three layer ABC-peroxidase technique (Vector Laboratories, Peterborough, England) using mouse anti-digoxin monoclonal antibody (Sigma, UK; Poole, Dorset). Diaminobenzidine tetrahydrochloride (DAB) was used as the chromogen. ${ }^{17}$

\section{Results}

EVALUATING OPTIMAL CONDITIONS FOR EBER HYBRIDISATION

From polyacrylamide gel electrophoresis and the subsequent blot, the oligonucleotides were shown to have incorporated dig-dUTP and to have a tail length in the range of $50-100$ nucleotides.

Stringency: The melting temperature for the oligonucleotide probes was estimated to be $60-62^{\circ} \mathrm{C}$, according to Maniatis. ${ }^{31}$ Using this figure as a guideline, post-hybridisation washes at various levels of stringency were performed, including $2 \times \mathrm{SSC}$ at room temperature; $0 \cdot 1$ $\times$ SSC at $42^{\circ} \mathrm{C}, 0.1 \times \operatorname{SSC}$ at $60^{\circ} \mathrm{C}$, and 0.1 $\times$ SSC at $70^{\circ} \mathrm{C}$. From the results of these experiments we chose $0.1 \times \mathrm{SSC}$ at $55^{\circ} \mathrm{C}$ for the post-hybridisation washes. At this stringency condition, the hybridisation signal was 
seen only in EBV positive cell lines. At lower stringency conditions, weak non-specific hybridisation was present in HSB-2 cells, although not in other cell lines.

Denaturation: Probe and target EBER RNA were denatured at $70^{\circ} \mathrm{C}$ in a hot air oven for eight minutes or at about $104^{\circ} \mathrm{C}$ in a microwave (Toshiba), also for eight minutes. High temperature microwave denaturation gave a stronger signal.

Digestion: Tissue sections were digested at a range of proteinase $K$ concentrations $(10-1000 \mu \mathrm{g} / \mathrm{ml})$. All the tissues examined in this study required digestion: at concentrations less than $100 \mu \mathrm{g} / \mathrm{ml}$ for optimal EBER signal detection. This is about one fifth to one tenth of that required for optimal BamH1 $\mathrm{W}$ probe hybridisation. With no digestion, the signal was completely abolished for $\mathrm{BamH} 1 \mathrm{~W}$ probe and considerably reduced for EBER detection.

Probe concentration: A range of EBER-1 and EBER-2 probe concentrations were evaluated $(10-1000 \mathrm{ng} / \mathrm{ml})$, both individually and in combination. A positive signal could easily be seen at concentrations as low as $10 \mathrm{ng} / \mathrm{ml}$ in EBV positive cell lines and nasopharyngeal carcinomas. The combination of the two EBER probes gave a stronger signal than either of the individual probes. The optimal signal was seen at $100 \mathrm{ng} / \mathrm{ml}$ and beyond this the intensity of the signal did not increase. At a concentration of $1000 \mathrm{ng} / \mathrm{ml}$, weak staining was observed in small infiltrating lymphocytes in Hodgkin's disease tissues, although not in nasopharyngeal carcinoma. A similar pattern of weak staining was also seen with a completely unrelated oligonucleotide used as a negative control. This suggests that this weak staining in small lymphocytes is non-specific. In keeping with this, the weak staining could be blocked by including $50 \mu \mathrm{g} / \mathrm{ml}$ of the unrelated unlabelled $30 \mathrm{mer}$ in the EBER hybridisation mix.

\section{SPECIFICITY}

Having optimised the EBER hybridisation conditions, various EBV positive and negative cell lines were tested to determine the specificity of the technique. Very strong nuclear hybridisation signal was seen in the EBV positive B95-8 cell line (not shown). A weaker, but nevertheless clearly positive signal was also seen in Namalwa and EBV positive lymphoblastoid cell lines. Furthermore, the hybridisation signal was exclusively present in the nucleus, sparing the nucleolus. The intensity of the signal varied from cell to cell in the same section. The EBV negative cell line, Ramos, and sections of normal tonsil were consistently negative, as were HSB-2 and fibroblast cell cultures infected with HHV-6 and cytomegalovirus, respectively. To determine if the hybridisation signal observed using EBER probes was specific, a competitive inhibition assay was set in which the EBER signal was found to be inhibited if a 1000-fold excess of unlabelled probe was included in the hybridisation mix. Further confirmation of the specificity of the EBER oligonucleotide probes was obtained by treating sections from Hodg- kin's disease and nasopharyngeal carcinoma tissue with $\mathrm{RNase}^{17}$ before hybridisation. No signal was seen in any of the RNase treated preparations, while the corresponding untreated sections were strongly positive (figs $1 \mathrm{~A}$ and $\mathrm{B}$ ).

TUMOUR TISSUES

Except for two cases of Hodgkin's disease, all the cases studied were known to be positive for EBV DNA by PCR, or NISH, or both. ${ }^{1617}$ The hybridisation signal using the EBER probes was very intense with a diffuse pattern of staining confined to the nucleus but sparing the nucleolus (figs $1 \mathrm{~A}$ and $2 \mathrm{~A}$ ). Comparing the sensitivity of EBER hybridisation and the BamH1 $W$ probe hybridisation method, the former was found to be much more sensitive on all the tissues tested. The hybridisation signal seen using BamH1 $\mathrm{W}$ probe was much more difficult to discern. These signals are seen as small dots within the nucleus and required a high power objective lens for identification (fig 2B). With BamH1 $W$ probe, a high degree of digestion may often be needed for optimal signal detection and inevitably this results in a loss of tissue morphology. Additionally, in those cases which were EBV positive, almost all morphologically malignant cells gave a positive signal with the EBER probes, in contrast to BamH1 $\mathrm{W}$ probe, which resulted in only a proportion of malignant cells giving a positive signal. In both methods the signal was confined to cells showing the morphological characteristics of malignancy and was not seen in the infiltrating lymphocytes. There was considerable variation in the intensity of the hybridisation signal from one case to another and even from cell to cell in the same section. Staining seen in cases of nasopharyngeal carcinoma was consistently stronger than that seen in cases of Hodgkin's or non-Hodgkin's lymphoma.

\section{Discussion}

Localising the presence of EBV to malignant cells is important for determining any possible aetiological role of the virus in tumorigenesis. Techniques such as Southern blotting and the polymerase chain reaction are sensitive but lack this basic criterion. In situ hybridisation fulfils this objective, and with EBV it has been refined over the years to give very sensitive results. The presence of single copies of EBV can be detected using a non-isotopically labelled BamH1 $\mathrm{W}$ fragment probe on cell lines. ${ }^{1718}$ However, there are several drawbacks with this technique. Not only is the positive signal difficult to discern due to the small dot pattern of hybridisation, but the tissue morphology may also be poor as a result of the high proteinase $\mathrm{K}$ digestion that is often required. Additionally, the preparation of the BamH1 $W$ fragment probe is in itself time consuming and expensive. Moreover, the sensitivity is questionable on archival material with both isotopic and non-isotopic methods. ${ }^{1832}$

Here we report a novel approach for the 

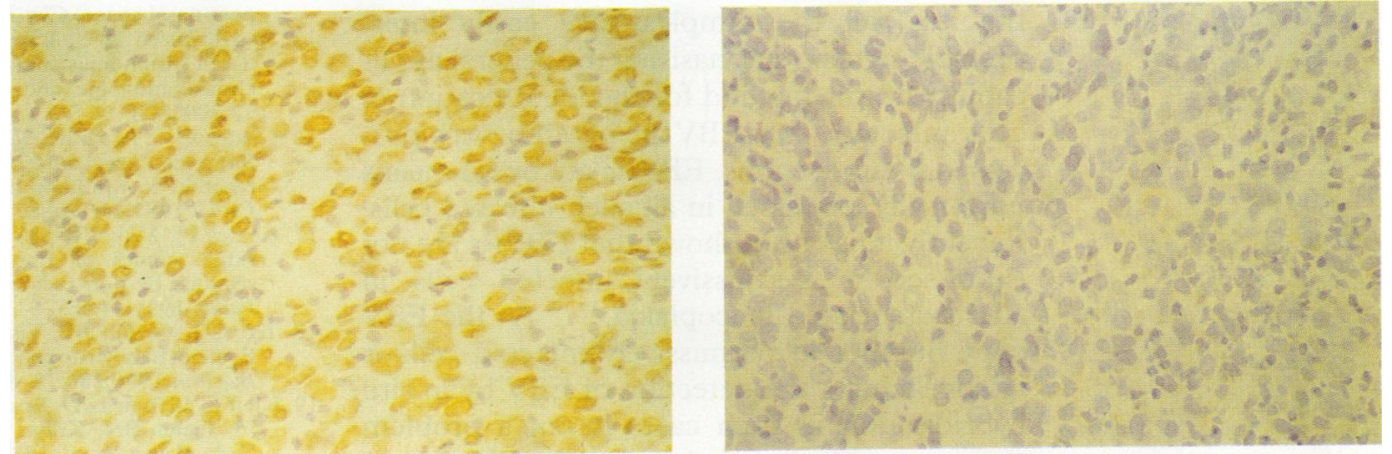

Figure 1 A case of undifferentiated nasopharyngeal carcinoma. (A) Hybridisation with $100 \mathrm{ng} / \mathrm{ml}$ of digoxigenin labelled EBER-1 probe; proteinase $K$ digestion $50 \mu \mathrm{g} / \mathrm{ml}$. Very strong nuclear staining, sparing the nucleolus is seen only in the morphologically malignant cells. (B) Specificity assay; RNase treatment $(200 \mu \mathrm{g} / \mathrm{ml})$ before hybridisation with $100 \mathrm{ng} / \mathrm{ml}$ of EBER-1 probe.

detection of EBV in paraffin wax embedded tissues, using EBV encoded small RNAs as targets for digoxigenin labelled synthetic oligonucleotide probes. We have shown that this technique is significantly more sensitive than other in situ hybridisation methods used for the detection of EBV, in terms of intensity of the signal, the proportion of cells giving a positive signal, and the ease of interpreting a positive result. The hybridisation pattern is morphologically distinct, staining only the nucleus while sparing the nucleolus. Low proteinase $\mathrm{K}$ digestion is required, hence tissue morphology is preserved.

A similar approach for the detection of EBV has recently been described by Wu et al, who have shown that EBERs are expressed in Hodgkin's disease ${ }^{26}$ and nasopharyngeal carcinoma, ${ }^{27}$ using in situ hybridisation. In the former report ${ }^{3} \mathrm{H}$ labelled EBER-1 riboprobe was used while in the latter study both radiolabelled and digoxigenin labelled EBER-1 riboprobe was used. The preparation of riboprobe by cloning EBER sequences in plasmids and the subsequent in vitro transcription is an expensive and time consuming process. Riboprobes are relatively unstable and require RNase free equipment when handling. In contrast, we have used short synthetic oligonucleotides to show the expression of EBERs in cases of Hodgkin's and non-Hodgkin's lymphoma, and nasopharyngeal carcinoma. The preparation of the oligonucleotide probes is simple, relatively inexpensive, and very rapid.
Although the oligonucleotide probes are less sensitive in themselves, the extremely high EBER copy number in latently EBV infected cells compensates for this loss in sensitivity. The overall technique is sensitive and the results easy to interpret due to the intense hybridisation signal, which is morphologically characteristic of EBER distribution. ${ }^{23}$ Generally all our positive cases showed a diffuse pattern of staining with EBER probes, in contrast to the dot pattern of EBER hybridisation observed by others. ${ }^{2327}$ This apparent discrepancy in the two sets of results may be due to the small size of the oligonucleotide probes and the high temperature denaturation used in our protocol, both of which may facilitate a greater access for the probes to hybridise to the target EBERs. We found that high temperature microwave denaturation at about $104^{\circ} \mathrm{C}$ for eight minutes was essential for obtaining an optimal signal. This is not altogether surprising because it is well known that EBERs exhibit extensive intramolecular base pairing and a stable secondary structure. ${ }^{22} 28$

In the cases of nasopharyngeal carcinoma and Hodgkin's lymphoma examined the EBER hybridisation signal was consistently stronger in the former than in the latter. Furthermore, considerable variation in signal intensity was observed from cell to cell in the same section, consistent with reported observations. ${ }^{27}$ These findings indicate that the EBER copy number varies from cell to cell which may correlate with differing EBV copy number. ${ }^{21}$ None
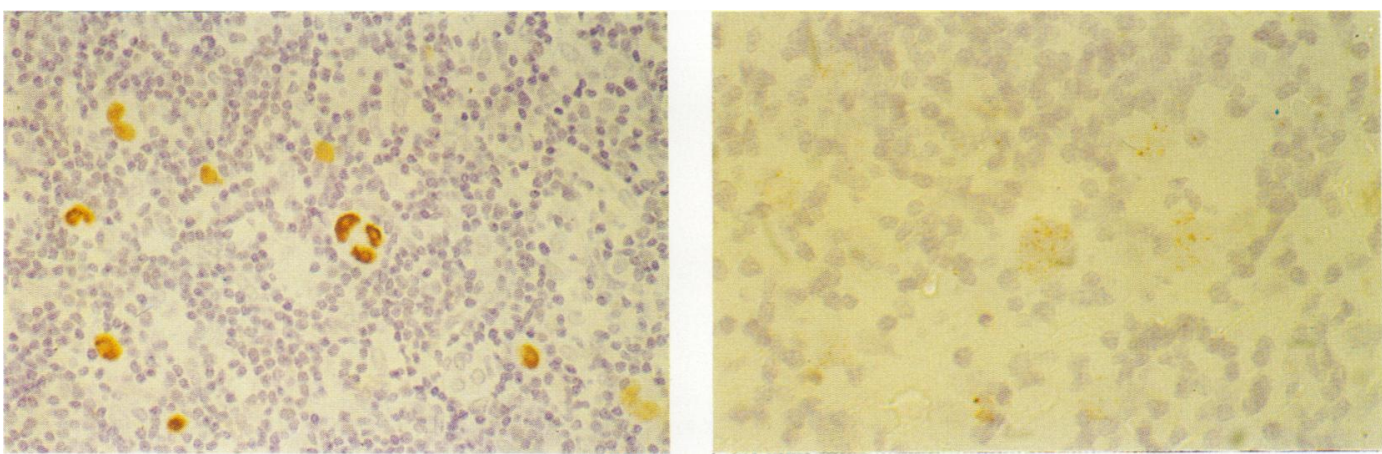

Figure 2 A case of Hodgkin's disease. (A) Hybridisation with a combination of EBER probes $(100 \mathrm{ng} / \mathrm{ml})$. Digestion: $30 \mu \mathrm{g} / \mathrm{ml}$ Strong diffuse pattern of staining seen in morphologically malignant cells. (B) Hybridisation with $1 \mu \mathrm{g} / \mathrm{ml}$ of BamH1W probe. Digestion: $100 \mathrm{\mu g} / \mathrm{ml}$. Hybridisation signal is seen as small dots in only the large neoplastic cells (oil immersion). 
the less, all the samples gave easily interpretable signals, emphasising the general applicability of this method for the identification of cells infected with EBV in paraffin wax processed tissue sections. EBERs are by no means universally expressed in all such infected cells. Recently it has been shown that EBERs are not expressed in permissively infected cells in AIDS associated leucoplakia. ${ }^{334}$ As the EBV copy number in permissively infected cells is relatively high, the detection of EBV by in situ hybridisation in such cases is not a problem and can easily be done using the BamH1 W probe or oligonucleotide probe to EBV DNA. $^{35}$

We thank P Crocker for the photography and $M$ Wilks for the oligonucleotide synthesis. This project was funded by the join research board of St Bartholomew's Hospital.

1 Henle W, Diel V, Kohn G, Zur Hausen H, Henle G. Herpestype virus and chromosome marker in normal leukocytes after growth with irradiated Burkitt cell. Science 1967;157:1064-5.

2 Pope JH, Horne MK, Scot W. Transformation of fetal human leukocytes in vitro by filtrates of a human leukaemic cell line containing herpes-like virus. Int $\%$ Cancer 1968;3:857-66.

3 Shapiro IM, Volsky DJ. Infection of normal human epithelial cells by Epstein-Barr virus. Science 1983;219. 1225-8.

4 Miller G. Epstein-Barr virus biology, pathogenesis, and medical aspects. In: Fields BN, Knipe DM, eds. Virology 2nd ed. New York: Raven Press, 1990:1921-57.

5 Epstein MA, Achong BG, Barr YM. Virus particles in cultured lymphoblasts from Burkitt's lymphoma. Lancet 1964;i:702-3.

6 Zur Hausen H, Schutte-Holthausen H, Klein G, et al. EBV DNA in biopsies of Burkitt tumour and anaplastic carcinoma of the nasopharynx. Nature 1970;228: 1056-8.

7 Klein G, Giovanella BC, Lindahl T, et al. Direct evidence for the presence of Epstein-Barr virus DNA and nuclear antigen in malignant epithelial cells from patients with antigen in malignant epithelial cells from patients with poorly differentiated carcinoma of the
Natl Acad Sci USA 1974;71:4737-41.

8 Henle G, Henle W, Diehl V. Relation of Burkitt's tumorassociated herpes-type virus to infectious mononucleosis. Proc Natl Acad Sci USA 1968;56:94-101.

9 Randhawa PS, Yousem SA, Paradis IL, et al. The clinical spectrum, pathology and clonal analysis of Epstein-Bar virus-associated lymphoproliferative disorders in heartlung transplant recipients. Am f Clin Pathol 1989, 92:177-85.

10 Weiss LM, Movahed LA, Warnke RA, Sklar J. Detection of Epstein-Barr virus genomes in Reed-Sternberg cells of Hodgkin's disease. N Engl f Med 1989;320:502-6.

11 Rouah E, Rogers BB, Wilson DR, Kirkpatrick JB, Buffone GJ. Demonstration of Epstein-Barr virus in primary GJ. Demonstration of Epstein-Barr virus in primary central nervous system lymphoma by the polymerase chain reaction $1990 ; 21: 545-50$.

12 Eversole LR, Stone CE, Beckmann AM. Detection of EBV and HPV DNA sequences in oral 'hairy' leukoplakia by in situ hybridization. $\mathcal{f}$ Med Virol 1988;26:271-7.

13 Jones JF, Shurin M, Abramowsky C. T-cell lymphoma containing Epstein-Barr viral DNA in patients with chronic Epstein-Barr virus infections. N Engl $\mathcal{f}$ Med 1988;318:733-41.

14 De Schryver A, Friberg S Jr, Klein G, et al. Epstein-Barr virus-associated antibody patterns in carcinoma of the post-nasal space. Clin Exp Immunol 1969;5:443-59.

15 Su I-J, Hsieh H-C, Lin K-H, et al. Aggressive peripheral T-cell lymphomas containing Epstein-Barr virus DNA: A clinicopathol

16 Coates PJ, d'Ardenne AJ, Khan G, Kangro HO, Slavin G. Simplified procedures for applying the polymerase chain reaction to routinely fixed paraffin wax sections. F Clin reaction to routinely

17 Coates PJ, Mak WP, Slavin G, d'Ardenne AJ. Detection of single copies of Epstein-Barr virus in paraffin wax sections by non-radioactive in situ hybridization. $f$ Clin Pathol 1991;44:487-91.

18 Teo CG, Griffin BE. Visualization of single copies of the Epstein-Barr virus genome by in situ hybridization. Anal Biochem 1990;186:78-85.

19 Kieff E, Liebowitz D. Epstein-Barr virus and its replication In: Fields BN, Knipe DM, eds. Virology. 2nd ed. New York: Raven Press, 1990:1889-920.

20 Lerner MR, Andrews NC, Miller G, Steitz JA. Two small RNAs encoded by Epstein-Barr virus and complexed with protein are precipitated by antibodies from patients with systemic lupus

21 Arrand JR, Rymo L. Characterization of the major EpsteinBarr virus-specific RNA in Burkitt lymphoma-derived cells. $\mathcal{F}$ Virol 1982;41:376-89.

22 Glickman JN, Howe JG, Steitz JA. Structural analysis of EBER-1 and EBER-2 ribonucleoprotein particles presen in Epstein-Barr virus-infected cells. F Virol 1988;62 902-11.

23 Howe JG, Steitz JA. Localization of Epstein-Barr virusencoded small RNAs by in situ hybridization. Proc Nat Acad Sci USA 1986;83:9006-10.

24 Toczysky DPW, Steitz JA. EAP, a highly conserved cellular protein associated with Epstein-Barr virus small RNAs (EBERs). EMBO f 1991;10:459-66.

25 Bhat RA, Thimmappaya B. Two small RNAs encoded by Epstein-Barr virus can functionally substitute for virusEpstein-Barr virus can functionally substitute for virus-
associated RNAs in the lytic growth of adenovirus 5. Proc associated RNAs in the lytic growth of
Natl Acad Sci USA 1983;80:4789-93.

26 Wu T-C, Mann RB, Charache P, et al. Detection of EBV gene expression in Reed-Sternberg cells of Hodgkin's disease. In 7 Cancer 1990;46:801-4.

27 Wu T-C, Mann RB, Epstein JI, et al. Abundant expression of EBER 1 small nuclear RNA in nasopharyngeal carcinoma. Am f Pathol 1991;138:1461-9.

28 Howe JG, Shu M-D. Isolation and characterization of the genes for two small RNAs of herpesvirus papio and their RNAs. $₹$ Virol 1988;62:2790-8.

29 Schmitz GG, Walter T, Seibel R, Kessler C. Nonradioactive labeling of oligonucleotides in vitro with the hapten labeling of oligonucleotides in vitro with the hapten digoxigenin by tailing with

30 Coates PJ, Hall PA, Buttler MG, d'Ardenne AJ. Rapid technique of DNA-DNA in situ hybridization on formalin fixed tissue sections using microwave irradiation. $f$ Clin Pathol 1987;40:865-9.

31 Sambrook J, Fritsch EF, Maniatis T. Molecular cloning: a laboratory manual. 2nd edn. Cold Spring Harbor: Cold Spring Harbor Laboratory Press, 1989:11-46.

32 Hamilton-Dutoit SJ, Delecluse HJ, Lenoir G, Pallesen G. Detection of Epstein-Barr virus genomes in AIDS related lymphomas: Sensitivity and specificity of in situ hybridization compared with Southern blotting. $f$ Clin Pathol 1991;44:676-80.

33 Young LS, Brooks L, Gilligan $\mathrm{K}$, et al. Epstein-Barr virus replication and gene expression in oral 'hairy' leukopladiseases 1988. Clifton, New Jersey: Humana Press, diseases 1988.
1989:329-31.

34 Gilligan K, Rajadurai P, Resnick L, Raab-Traub N. EpsteinBarr virus small nuclear RNAs are not expressed in permissively infected cells in AIDS-associated leukoplakia. Proc Natl Acad Sci USA 1990;87:8790-4.

35 Montone KT, Budgeon LR, Brigati DJ. Detection of Epstein-Barr virus genomes by DNA hybridization with terminally biotin-labelled synthethic oligonucleotide probe from the EBV NOT 1 and PST 1 tandem repeat regions. Modern Pathol 1990;3:89-96. 